\title{
KOMPETISI DAN PEMBAGIAN SUMBER DAYA PAKAN KOMUNITAS IKAN DI WADUK WONOGIRI
}

\author{
Kunto Purnomo*)
}

\begin{abstract}
ABSTRAK
\end{abstract}
Waduk Wonogiri (6.480 ha) merupakan bagian dari sistem DAS Bengawan Solo. Fungs utamanya untuk irigasi dan tergolong sangat subur (eutropik). Produksi perikanannya antara tahun 1996-1998 mencapai 3.796-4.248 ton/tahun di mana 75-78\% di antaranya berasal dari hasil penangkapan ikan. Penelitian tentang aspek kompetisi dan pembagian sumber daya makanan di Waduk Wonogiri telah dilakukan dari bulan Juli sampai Desember 1999. Tujuan penelitian untuk mendapatkan data dan informasi kondisi sumber daya ikan dengan penekanan terhadap beberapa aspek bio-ekologi yang terkait dengan kehidupan ikan. Hasil penelitian menunjukkan bahwa kondisi lingkungan perairan waduk tergolong baik untuk kehidupan ikan. Jenis ikan yang ditemukan selama penelitian sebanyak 15 jenis dan jenis-jenis yang paling dominan ialah: tawes (Barbodes gonionotus), lukas (Dangila cuvieri), palung (Hampala macrolepidota), dan nila (Oreochromis niloticus). Sumber daya makanan alami yang dimanfaatkan ikan ialah: tumbuhan air $(31 \%)$, ikan (25\%), udang (23\%), fitoplankton (12\%), detritus ( $8 \%$ ), dan zooplankton (1\%). Ikan nila yang diintroduksikan pada sekitar tahun 1970 saat ini telah berkembang dengan baik. Ikan ini bersifat generalis dan kebiasaan makanannya sama dengan ikan asli waduk sehingga terjadi kompetisi dalam mendapatkan makanannya. Kehadiran ikan patin sejak tahun 1994 ternyata mampu memanfaatkan sumber daya pakan yang tidak banyak dimanfaatkan oleh jenis ikan asli sehingga peluang kompetisinya kecil Prospeknya ke depan sangat baik sehingga upaya peningkatan stok diharapkan akan dapat meningkatkan pendapatan nelayan setempat

ABSTRACT: Competition and resource partitioning along the trophic niche dimension of fishes in Wonogiri Reservoir. By: Kunto Purnomo

Wonogiri Reservoir (6,480 ha) is a part of the Bengawan Solo river basin, which is also a typical irrigation reservoir and eutrophic. The total fish production of 1996-1998 ranged from 3,796 to 4,248 ton per year of which about $75-78 \%$ came from catch production

Research on the competition and resource partitioning along the trophic niche of fishes in Wonogiri Reservoir was conducted from July to December 1999. The aim of this study was to investigate existing condition of fish resources in the reservoir, with the emphasis on some important bio-ecological aspects related to fish life. Results of this study showed that in general the water quality of Wonogiri Reservoir was suitable for aquatic life. Main food resources consumed by fish in this reservoir were aquatic plants (31\%), fish (25\%), shrimp (23\%), phytoplankton (12\%), detritus (8\%), and zooplankton $(1 \%)$. Fifteen fish species were found in this reservoir, dominated by tawes (Barbodes gonionotus), lukas (Dangila cuvieri), palung (Hampala macrolepidota), and nila (Oreochromis niloticus). Nila which was introduced around 1970's, was competitively dominant and able to capture niches formerly occupied by the indigenous riverine fish species (generalist), while the pangasius (Pangasius hypophthalmus) was able to occupy an empty niche when introduced in the reservoir and consquently did not compete with the indigenous fish species (specialist).

KEYWORDS: Niche breadth, niche overlap, resource partitioning, stock enhancement

\section{PENDAHULUAN}

Produksi perikanan Waduk Wonogiri (6.480 ha) antara tahun 1996-1998 mencapai 3.796-4.248 ton/ tahun di mana $75-78 \%$ di antaranya berasal dari hasil tangkapan. Program peningkatan produksi tangkapan ikan melalui upaya peningkatan stok (stock enhancement) yang berupa penebaran berbagai jenis ikan sudah dilaksanakan sejak tahun 1981 tetapi hasilnya masih belum seperti yang diharapkan oleh para nelayan. Program tersebut di Waduk Wonogiri selain dimaksudkan untuk melestarikan sumber daya, juga bertujuan untuk meningkatkan gizi masyarakat melalui penyediaan ikan yang cukup dan terjangkau harganya

Upaya peningkatan stok (stock enhancement) merupakan salah satu teknik pengelolaan populasi ikan dengan cara memanipulasi stok yang ada agar populasinya meningkat, misalnya dengan penebaran, penebaran ulang dan introduksi ikan (Cowx, 1994,

' Peneliti pada Balai Penelitian Perikanan Air Tawar 
1998; Welcomme \& Bartley, 1998). Umumnya upaya tersebut sering dilaksanakan dengan kurang mendasarkan pada pertimbangan data dan informasi secara ilmiah, misalnya ketersediaan makanan alami, struktur komunitas ikan dan penentuan jumlah serta jenis ikan yang akan ditebarkan sehingga menyulitkan dalam pelaksanaan monitoring dan evaluasi keberhasilan maupun penyebab kegagalannya (Piet, 1996; Welcomme \& Bartley, 1998)

Struktur dan fungsi komunitas ikan di suatu perairan dikendalikan oleh suatu mekanisme yang bersifat deterministik yaitu pengendalian secara bottom-up misalnya ketergantungan pada produsen primer, dan/atau dapat pula secara stochastik yaitu pengendalian secara atau top-down misalnya dikendalikan oleh predator (Giller, 1984). Kelimpahan suatu jenis ikan ditentukan oleh responsnya terhadap kondisi lingkungan, yang selanjutnya menimbulkan interaksi biotik. Fenomena ini akan lebih mudah dipahami dengan cara melakukan studi terhadap aspek relung (niche) ekologinya yaitu yang mencakup dimensi makanan (trophic), keruangan (spatial), dan waktu (temporal). Dalam penelitian ini posisi dan peranan suatu jenis ikan dalam komunitasnya hanya akan dikaji menurut dimensi makanannya sebab dimensi tersebut dianggap "lebih penting" dibanding dua dimensi lainnya (Piet, 1996). Studi tentang ekologi makanan (feeding ecology) dapat mengungkapkan pendudukan suatu niche (niche occupation) oleh suatu jenis ikan serta kaitannya dengan jenis yang lain. Informasi yang diperoleh merupakan suatu data dasar yang diperlukan dalam program peningkatan stok (Cowx, 1994, 1998; Piet, 1996; Welcomme \& Bartley, 1998)

Berdasarkan permasalahan tersebut di atas maka tujuan penelitian ini ialah untuk mendapatkan data dan informasi tentang ketersediaan sumber daya makan alami, pola pemanfaatan sumber daya tersebut oleh ikan (niche partitioning) dan pengaruhnya terhadap struktur komunitas ikan di Waduk Wonogiri. Hasil penelitian diharapkan dapat berupa informasi tentang relung (niche) ekologi yang masih dapat dimanfaatkan secara optimal serta jenis ikan yang sesuai dengan hal itu.

\section{BAHAN DAN METODE}

Penelitian dilakukan di Waduk Wonogiri (Gambar 1) dari bulan Juli sampai Desember 1999, yaitu masing-masing mewakili musim kemarau (air waduk sedang surut) dan awal musim hujan (saat air waduk mulai naik). Aktivitas yang dilakukan mencakup kegiatan sejak pengumpulan data aspek lingkungan dan sumber daya ikan hingga penebaran ikan.
Metode sampling yang dipakai untuk mendapatkan data aspek bio-ekologi di lapangan ialah stratified random sampling (Nielsen \& Johnson, 1985), yaitu membagi wilayah perairan waduk menjadi lima stasiun penelitian (Gambar 1) yang masing-masing mewakili daerah inlet dan outlet, bagian tengah serta sisi timur dan barat waduk. Selanjutnya di tiap stasiun tersebut dilakukan pengukuran beberapa parameter kualitas air yang penting secara in-situ seperti suhu dan kecerahan air, konsentrasi oksigen terlarut, karbon dioksida, $\mathrm{pH}$ air, dan alkalinitas, serta pengambilan contoh plankton, bentos dan tumbuhan air untuk selanjutnya diamati di laboratorium. Hasil analisisnya dipergunakan sebagai gambaran tentang kondisi habitat/lingkungan sebagai tempat hidup ikan serta ketersediaan makanannya di alam. Contoh ikan diperoleh dari hasil tangkapan nelayan maupun dari hasil percobaan penangkapan memakai perlakuan gillnet monofilament dengan ukuran mata jaring 25,4 sampai $114,3 \mathrm{~mm}$. Setelah dicatat jenis dan ukuran panjangnya selanjutnya diambil contoh isi perutnya (saluran pencernaan) untuk dianalisis di laboratorium. Hasil analisis isi perut berguna untuk mengetahui kebiasaan dan makanan kesukaan ikan, luas dan tumpang tindih relung (niche breadth and overlap), peluang kompetisi dan struktur komunitasnya secara fungsional yaitu berdasarkan status tropik tiap jenis ikan (Colwell \& Futuyma, 1971; Piet, 1996)

Analisis untuk mengetahui kebiasaan makan ikan dilakukan memakai metode indek preponderan (Effendie, 1979). Luas relung (niche breadth) dan tumpang tindih relung (niche overlap) tiap jenis ikan dihitung memakai model dari Colwell \& Futuyma (1971) sebagai berikut:

dengan

$$
B_{i j}=\frac{1}{\sum_{j} p_{i j}{ }^{2}} \quad C_{i h}=1-0.5 \sum_{j}\left[p_{i j}-p_{h j}\right]
$$

$\mathrm{B}_{i}=$ luas relung spesies ke- $i$.

$\mathrm{p}_{i j}=$ proporsi individu spesies ke $-i$ dalam kelompok sumber daya $j$.

$\mathrm{C}_{i n}=$ tumpang tindih relung (niche overlap) antara kelompok spesies ke-i dan $j$. Nilai ini berkisar antara 0 sampai 1 . Indeks ini juga dipakai sebagai kriteria untuk menentukan peluang terjadinya kompetisi antar jenis ikan (Moyle \& Senanayake, 1984) sebagai berikut:

Bila $\mathrm{C}_{i n}<0,3$ maka peluang terjadinya kompetisi tergolong rendah.

- Bila $C_{i h}=0,3-0,7$ maka peluang terjadinya kompetisi tergolong sedang. 


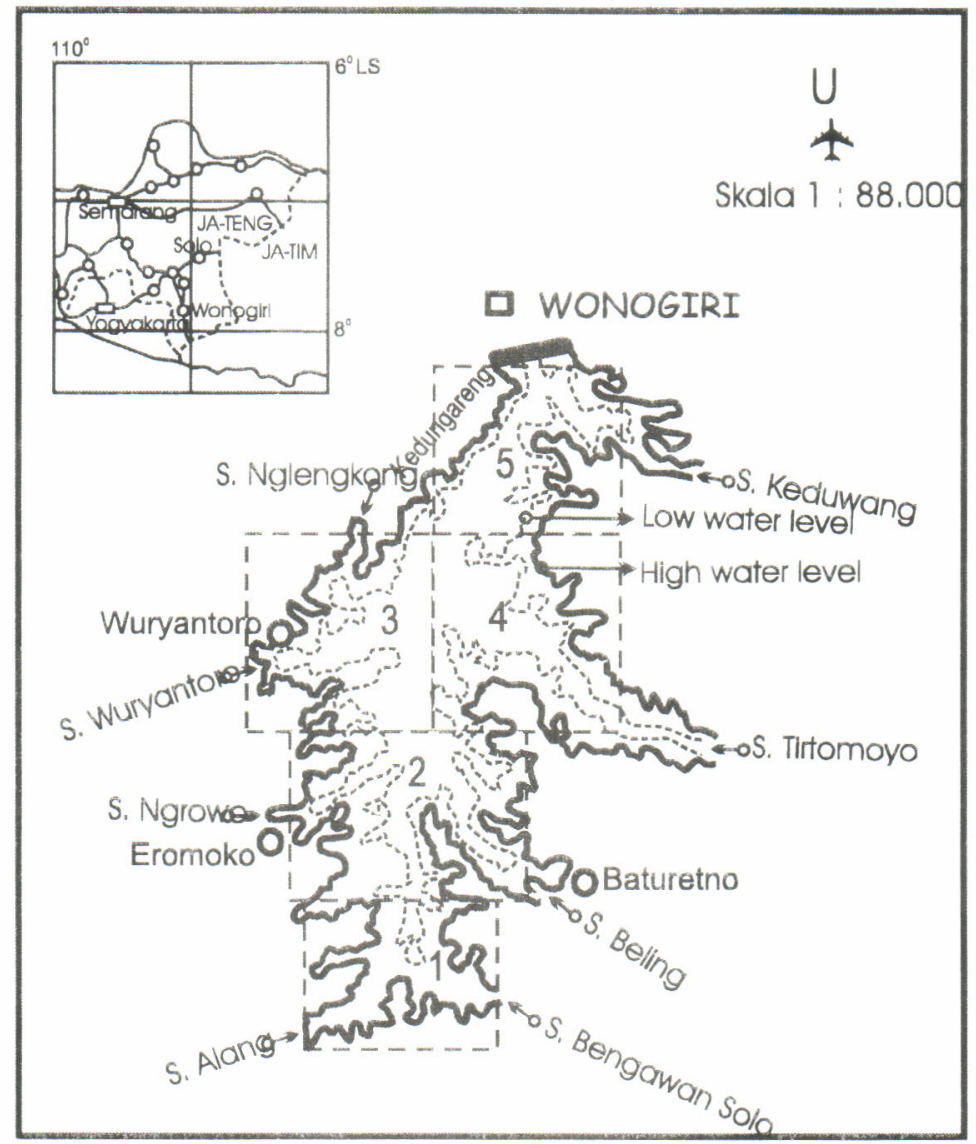

Gambar 1. Peta lokasi sampling di Waduk Wonogiri

Figure 1. Location of sampling stations in Wonogiri Reservoir

- $\quad$ Bila $C_{\text {in }}>0,7$ maka peluang terjadinya kompetisi tergolong tinggi.

\section{HASIL DAN BAHASAN}

Waduk Wonogiri terletak pada ketinggian antara 100-140 $\mathrm{m}$ di atas permukaan laut dan kedalaman maksimum $28 \mathrm{~m}$ (rata-rata 9-10 m). Waduk ini di sebelah utara dikelilingi oleh deretan pegunungan Gajahmungkur dan Baturagung, sedangkan di sebelah selatan oleh Pegunungan Sewu. Kedalaman perairan yang relatif dangkal serta lingkungan geografi seperti tersebut di atas menyebabkan hembusan angin dan terpaan gelombang yang cukup besar setiap hari sehingga perairan waduk ini selalu terlihat agak keruh (kecerahan air antara $30-80 \mathrm{~cm}$ ). Selain itu kekeruhan tersebut juga disebabkan oleh kelimpahan plankton yang cukup tinggi (kepadatannya antara 13.750-36.250 ind./L), bahkan lebih tinggi dibanding waduk lain seperti Saguling (Krismono et al., 1987), Cirata (Umar, 1991) dan Wadaslintang (Kartamihardja, 1992). Kepadatan plankton tersebut menyebabkan waduk ini tergolong perairan yang eutropik (sangat subur) dan merupakan sumber daya makanan alami yang sangat baik untuk kehidupan ikan. Kondisi lingkungan yang baik untuk kehidupan ikan juga diperlihatkan dari hasil pengukuran beberapa parameter kualitas air (Tabel 1), misalnya kandungan oksigen terlarut yang masih cukup baik hingga dasar perairan yaitu $9 \mathrm{~m}$ (Gambar 2). Tidak seperti halnya waduk-waduk yang lain, sampai sekarang belum pernah terjadi kematian ikan secara massal yang diakibatkan oleh kondisi lingkungan perairan. Tampaknya peluang tersebut sangat kecil sebab di bagian hulu Waduk Wonogiri (Sungai Bengawan Solo) tidak ada kegiatan industri dan daerah pemukiman penduduknya tidak terlalu padat.

Potensi sumber daya makanan alami yang bisa dimanfaatkan ikan antara lain ialah plankton yang kelimpahannya antara 13.750-36.250 ind./L, sedangkan komposisinya terdiri atas $87 \%$ fitoplankton dan 13\% zooplankton. Jenis plankton tersebut sebanyak 27 jenis dan tergolong ke dalam 6 famili (Tabel 2). Distribusi plankton tersebut secara vertikal masih cukup tinggi hingga kedalaman $3 \mathrm{~m}$ (Gambar 3). Distribusi kelimpahan tersebut agaknya dibatasi oleh kecerahan air yang rendah (Tabel 2) yang biasanya disebabkan oleh padatan tersuspensi yang tinggi. 
Tabel 1. Fisika kimia air Waduk Wonogiri

Table 1. Water physic chemical features of Wonogiri Reservor

\begin{tabular}{lc}
\hline \multicolumn{1}{c}{ Parameter/Parameters } & Range of value \\
\hline Suhu air/Water temparature $\left({ }^{\circ} \mathrm{C}\right)$ & $27.0-28.0$ \\
Kecerahan/Transparency $(\mathrm{cm})$ & $30.0-80.0$ \\
$\mathrm{pH}$ (unit) & $7.0-7.5$ \\
Oksigen terlarut/Dissolved oxygen $(\mathrm{mg} / \mathrm{L})$ & $4.0-9.0$ \\
Karbon dioksida/Free carbon dioxide $(\mathrm{mg} / \mathrm{L})$ & 0.00 \\
Alkalinitas/Alkalinity $\left(\mathrm{mg} \mathrm{CaCO} \mathrm{C}_{3} / \mathrm{L}\right)$ & $39.0-102.1$ \\
Fosfat/Phosphates $(\mathrm{mg} / \mathrm{L})$ & $0.010-0.116$ \\
\hline
\end{tabular}

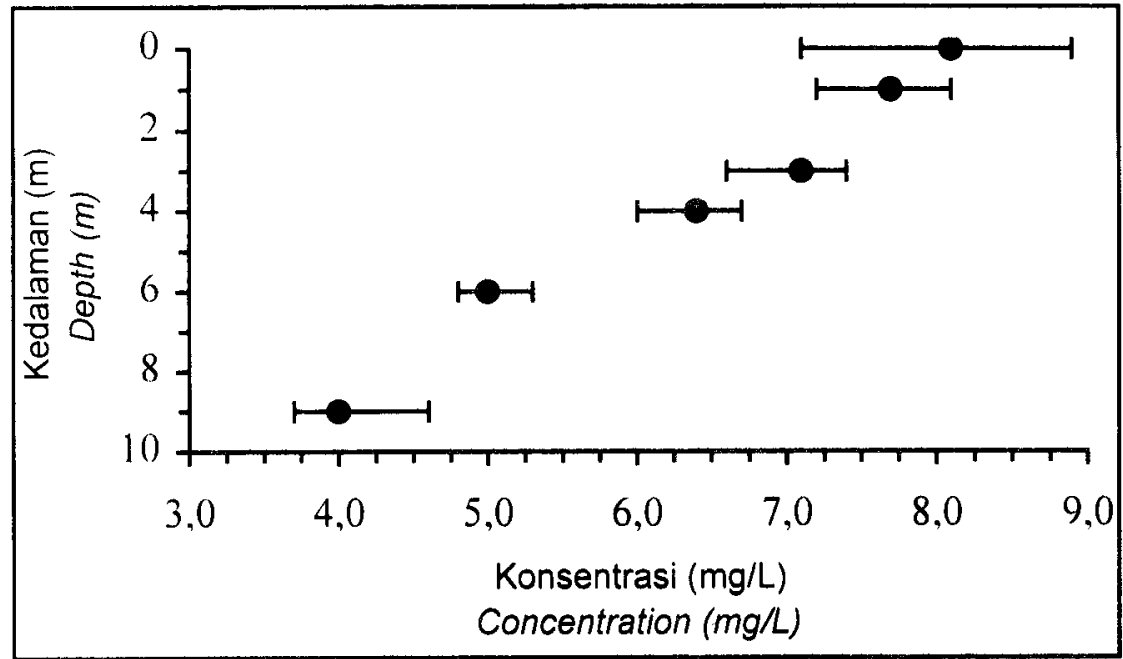

Gambar 2. Profil oksigen terlarut di Waduk Wonogiri

Figure 2. Profile of dissolved oxygen concentration Wonogiri Reservoir

Tabel 2. Komposisi jenis dan kelimpahan plankton di Waduk Wonogiri

Table 2. Species composition and abudance of plankton in Wonogiri Reservoir

\begin{tabular}{lcc}
\hline \multicolumn{1}{c}{$\begin{array}{c}\text { Parameter } \\
\text { Parameters }\end{array}$} & $\begin{array}{c}\text { Kisaran } \\
\text { Range of value }\end{array}$ & $\begin{array}{c}\text { Kelimpahan (ind./L) } \\
\text { Abundance (individu/L) }\end{array}$ \\
\hline Chlorophyceae & 10 & $5000-16250$ \\
Cyanophyceae & 6 & $2000-12750$ \\
Bacillariophyeae & 6 & $1250-9000$ \\
Protozoa & 4 & $1000-6000$ \\
Copepoda & 2 & $1000-3500$ \\
Rotifera & 1 & $1500-3500$ \\
\hline
\end{tabular}

Sumber daya makanan alami berupa benthos hanya terdiri atas kelompok Molusca (Potamopyrgus coronatus dan Pleurocera acuta) dan Anelida (Peloscolex variegatus), itupun kepadatannya sangat rendah (85-210 ind $\left./ \mathrm{m}^{2}\right)$. Kelimpahan organisme ini umumnya memang rendah dan hanya dijumpai di daerah litoral. $\mathrm{Hal}$ ini antara lain dikarenakan dasar perairan waduk yang keras dan agak berkapur serta kandungan detritus yang rendah pula.
Potensi sumber daya makanan alami lainnya yang bisa dimanfaatkan oleh ikan ialah tumbuhan air makrofita sejenis ganggang yaitu Hydrilla verticillata dan Ceratophyllum demersum yang terdapat di daerah litoral, terutama di bagian timur waduk. Jenis lainnya seperti kiyambang (Salvinia molesta) dan kiapu (Pistia stratiotes) hanya ditemukan secara soliter di perairan bagian tengah akibat terbawa oleh arus Sungai Bengawan Solo 


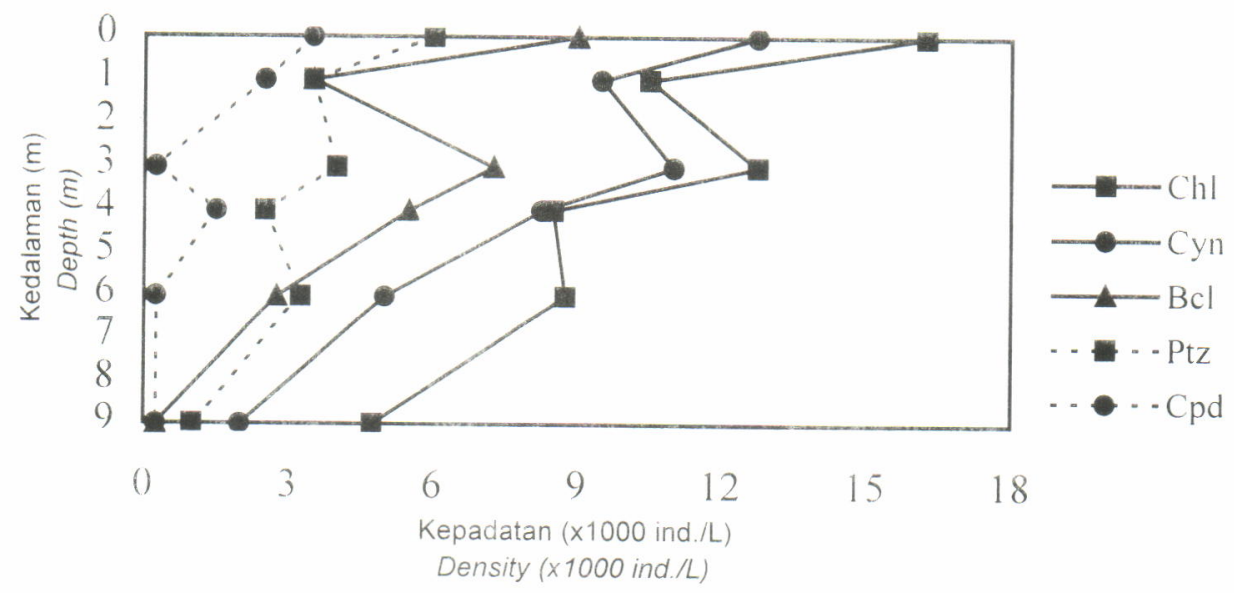

Gambar 3. Distribusi vertikal plankton di Waduk Wonogiri

Figure 3. Vertical distribution of plankton in Wonogiri Reservoir

Hasil pengamatan terhadap hasil tangkapan nelayan maupun dari hasil percobaan penangkapan memakai gillnet perlakuan menunjukkan bahwa struktur komunitas ikan di Waduk Wonogiri terdiri atas 15 jenis ikan (Gambar 4). Jumlah jenis tersebut sedikit lebih banyak dibanding yang pernah ditemukan pada tahun 1988 yaitu sebanyak 12 jenis (Kartamihardja et al., 1989). Jenis ikan yang tergolong dominan berturut-turut ialah tawes
$40,5 \mathrm{~cm}$ dan bobot antara 300-1.400 g). Produksinya pada tahun 1998 mencapai 472 ton/tahun atau sekitar 10-14,3\% dari total hasil tangkapan ikan. Ikan pangasius (Pangasius hypophthalmus) juga merupakan hasil introduksi secara tidak disengaja yaitu akibat hancurnya keramba jaring apung milik suatu perusahaan swasta pada tahun 1994. Ikan ini juga dapat tumbuh dengan baik (panjang antara 67 $80 \mathrm{~cm}$ dan bobot antara 3.425-5.500 g). Tampaknya

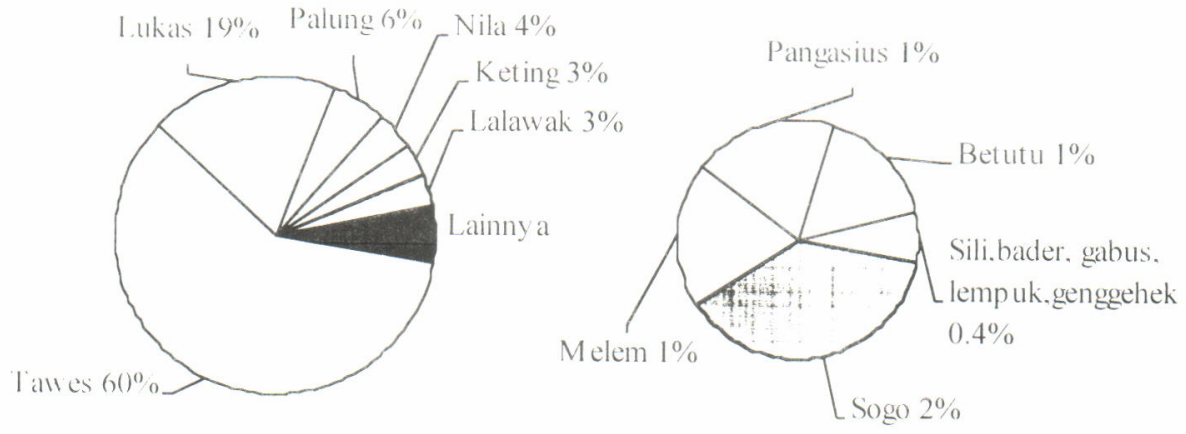

Gambar 4. Populasi ikan di Waduk Wonogiri

Figure 4. Fish population in Wonogiri Reservoir

(Barbodes gonionotus), lukas (Dangila cuvieri), palung (Hampala macrolepidota), nila (Oreochromis niloticus), keting (Mystus nigriceps), dan lalawak (Barbodes bramoides). Selain ikan nila, jenis-jenis ikan tersebut di atas merupakan ikan asli Sungai Bengawan Solo (indigenous riverine species) yang sudah beradaptasi dengan lingkungan perairan waduk (lacustrine species). Ikan nila pertama kali diintroduksikan ke Waduk Wonogiri sekitar tahun 1970 dan hingga kini telah mampu hidup dan berkembang biak dengan baik (panjang antara 22,6- ikan pangasius mempunyai prospek ekonomi yang cukup baik sebab selain permintaan pasar yang cukup tinggi, juga harganya yang mencapai Rp $10.000,-/ k g$ tergolong tinggi dibanding jenis ikan hasil tangkapan lainnya.

Hasil analisis isi perut terhadap sepuluh jenis ikan yang ditemukan memperlihatkan bahwa sumber daya makanan alami yang banyak dimanfaatkan ikan ialah: tumbuhan air (31\%), ikan (25\%), udang $(23 \%)$, fitoplankton $(12 \%)$, detritus $(8 \%)$, dan zooplankton $(1 \%)$. Berdasarkan makanan kesukaannya (Gambar 


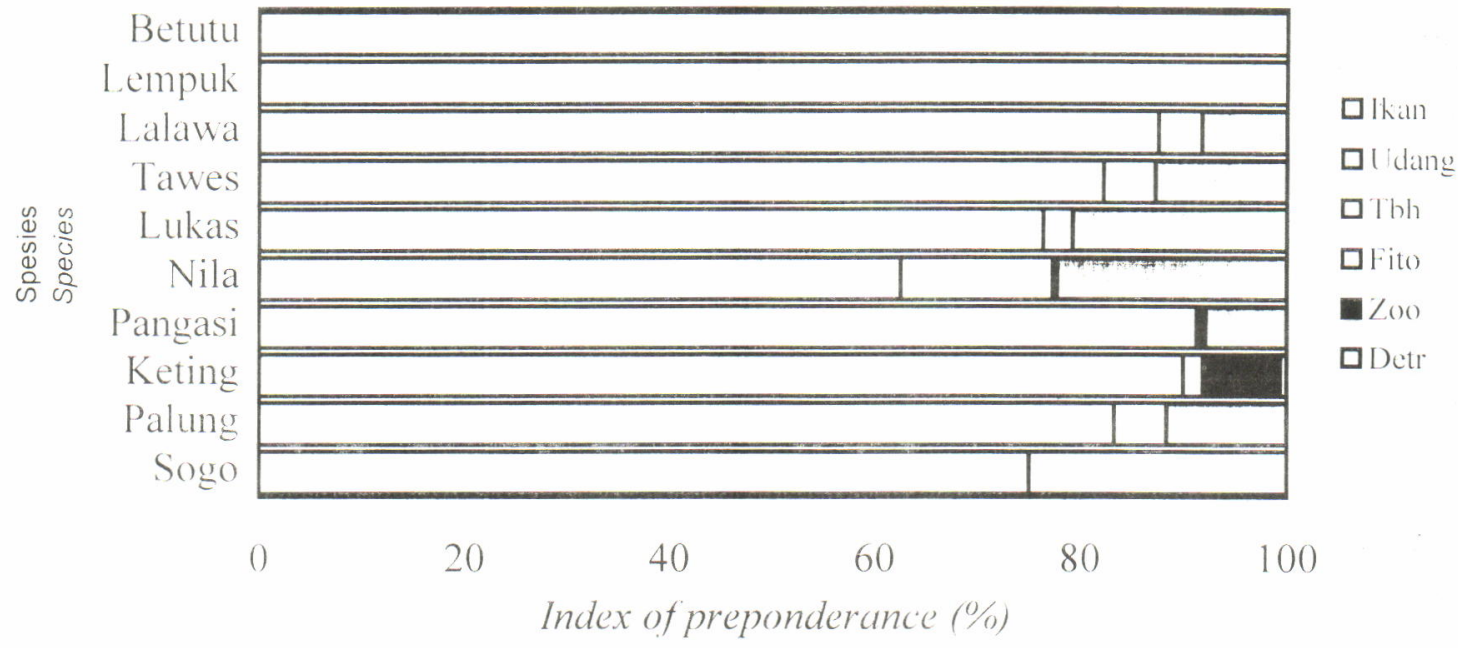

Gambar 5. Isi perut ikan di Waduk Wonogiri

Figure 5. Gut contents of fish in Wonogiri Reservoir

5), terlihat bahwa beberapa jenis ikan seperti nila, lukas, tawes, dan lalawak mempunyai relung ekologi yaitu banyak memanfaatkan tumbuhan air sebagai makanan utamanya; ikan keting, palung, dan sogo (Mystus nemurus) memanfaatkan anak ikan sebagai makanan utamanya; ikan lempuk (Callichrous bimaculatus) dan betutu (Oxyeleotris marmorata) makanan utamanya adalah udang dan satu-satunya jenis ikan yang paling banyak mengkonsumsi fitoplankton adalah ikan pangasius. Sumber daya pakan yang berupa detritus ternyata juga dikonsumsi oleh ikan nila, lukas, tawes, palung, dan lalawak walaupun hanya bersifat sebagai makanan tambahan.

Luas dan tumpang tindih relung (niche breadth dan niche overlap) dapat menggambarkan spesialisasi pemanfaatan pakan tiap jenis ikan serta peluang terjadinya kompetisi dalam mendapatkan makanan tersebut di antara jenis-jenis ikan yang ada. Luas relung menggambarkan proporsi jumlah jenis sumber daya pakan yang dimanfaatkan oleh suatu jenis ikan (Giller, 1984). Suatu organisme dikategorikan mempunyai luas relung yang lebar (maksimum) sehingga bersifat "generalis" adalah apabila organisme tadi memanfaatkan seluruh kelompok sumber daya pakan yang tersedia secara merata. Sebaliknya jenis organisme tersebut dikatakan bersifat "spesialis" apabila hanya tersebar dan memanfaatkan salah satu sumber daya yang ada sehingga luas relungnya sempit (minimum) atau spesialisasinya mencapai maksimum (Colwell \& Futuyma, 1971). Batasan kriteria generalis dan spesialis berdasarkan nilai luas relung, umumnya ditentukan secara subjektif (Piet, 1996).
Dari nilai luas dan tumpang tindih relung tiap jenis ikan (Tabel 3), dapat diketahui bagaimana posisi dan peranan tiap jenis ikan di dalam komunitasnya. Bila dikaitkan dengan Gambar 5, maka akan semakin jelas dapat diketahui relung ekologi yang masih lowong atau dapat dioptimalkan pemanfaatannya serta peluang terjadinya kompetisi antar jenis. Ikan nila, tawes, lukas, dan lalawak mempunyai luas relung yang lebar $\left(B_{i}=1,9-3,1\right)$ serta tumpang tindih relung yang mendekati nilai satu $\left(C_{\text {in }}=0,64-0,89\right)$. Dari dendrogram pengelompokan makanan (Gambar 6), terlihat bahwa peluang terjadinya kompetisi makanan di antara keempat jenis ikan tersebut tergolong cukup tinggi. Selama sumber daya makanan yang tersedia melimpah maka peluang kompetisi tersebut adalah kecil. Sebaliknya kalau menjadi faktor pembatas (limiting factor) maka akan ada populasi ikan yang terdesak sehingga ukuran individunya mengecil. Hal ini dapat terlihat dari hasil tangkapan jenis ikan tersebut yang semakin menurun.

Ikan palung dan sogo makanan utamanya anak ikan, luas relungnya agak lebar dan peluang terjadinya kompetisi makanan antar jenis ikan tidak terlalu tinggi (Tabel 3) sebab keduanya masih dapat memanfaatkan makanan lain seperti udang, detritus ataupun plankton (Gambar 5). Peluang terjadinya kompetisi tersebut juga dapat dilihat dari dendrogram pengelompokan jenis ikan berdasarkan kesamaan makanannya (Gambar 6). Ikan palung, sogo dan keting meskipun jenis makanan utamanya hampir sama (Gambar 5) dan termasuk dalam satu kelompok makanan (Gambar 6) tetapi peluang terjadinya kompetisi makanan relatif kecil (Tabel 3) sebab ketiganya masih dapat memanfaatkan sumber 
Tabel 3. Luas dan tumpang tindih relung ikan di Waduk Wonogiri

Table 3. Niche breach and overlap of fish in Wonogiri Reservoir

\begin{tabular}{lccccccccccc}
\hline \multirow{2}{*}{$\begin{array}{c}\text { Spesies } \\
\text { Species }\end{array}$} & $\begin{array}{c}\text { Luas relung } \\
\text { Niche } \\
\text { Breadth }\end{array}$ & \multicolumn{10}{c}{ Spesies/Species } \\
\cline { 3 - 12 } & Tawes & Lukas & Palung & Lalawak & Keting & Sogo & Pangasius & Lempuk & Betutu \\
\hline Nila & 3.143 & 0.738 & 0.783 & 0.347 & 0.637 & 0.092 & 0.000 & 0.231 & 0.000 & 0.000 \\
Tawes & 2.194 & - & 0.853 & 0.347 & 0.899 & 0.018 & 0.000 & 0.190 & 0.000 & 0.000 \\
Lukas & 2.179 & - & - & 0.313 & 0.759 & 0.018 & 0.000 & 0.146 & 0.000 & 0.000 \\
Palung & 1.981 & - & - & - & 0.314 & 0.310 & 0.653 & 0.180 & 0.000 & 0.000 \\
Lalawak & 1.890 & - & - & - & - & 0.018 & 0.000 & 0.183 & 0.000 & 0.000 \\
Keting & 1.780 & - & - & - & - & - & 0.292 & 0.121 & 0.000 & 0.000 \\
Sogo & 1.648 & - & - & - & - & - & - & 0.000 & 0.269 & 0.269 \\
Pangasius & 1.533 & - & - & - & - & - & - & - & 0.000 & 0.000 \\
Lempuk & 1.000 & - & - & - & - & - & - & - & - & 1.000 \\
Betutu & 1.000 & - & - & - & - & - & - & - & - & - \\
\hline
\end{tabular}

daya pakan yang lain seperti udang, zooplankton ataupun detritus (Gambar 5).

Ikan patin merupakan salah satu jenis ikan yang paling banyak mengkonsumsi fitoplankton $( \pm 91,3 \%)$ sebagai makanan utamanya, selain detritus dan zooplankton sebagai makanan pelengkap dan tambahannya (Gambar 5). Dari Tabel 3 terlihat bahwa luas relungnya termasuk sempit $\left(B_{i}=1,533\right)$ sehingga ikan ini tergolong spesialis dan selektif dalam mencari makanannya yang berupa fitoplankton. Jenis ikan ini mampu memanfaatkan relung makanan berupa plankton yang tidak banyak dimanfaatkan oleh ikan lainnya sehingga peluang kompetisinya juga tergolong rendah. Tampaknya jenis ikan ini mempunyai prospek ke depan yang cukup baik sebab selain mampu memanfaatkan relung yang ada secara optimal, juga disukai masyarakat karena harga jualnya tinggi. Pertimbangan semacam ini seharusnya mendasari perencanaan upaya peningkatan stok (stock enhancement) di perairan umum (Piet, 1996: Welcomme \& Bartley, 1998).

Ikan lempuk dan betutu sangat selektif dalam memilih makanannya yang berupa udang (Gambar 5), sehingga bersifat karnivora sejati. Keduanya mempunyai spesialisasi makanan yang tinggi sehingga peluang kompetisinya juga sangat tinggi (maksimum). Hasil tangkapan ikan betutu akhir-akhir ini meningkat dengan pesat dan permintaan

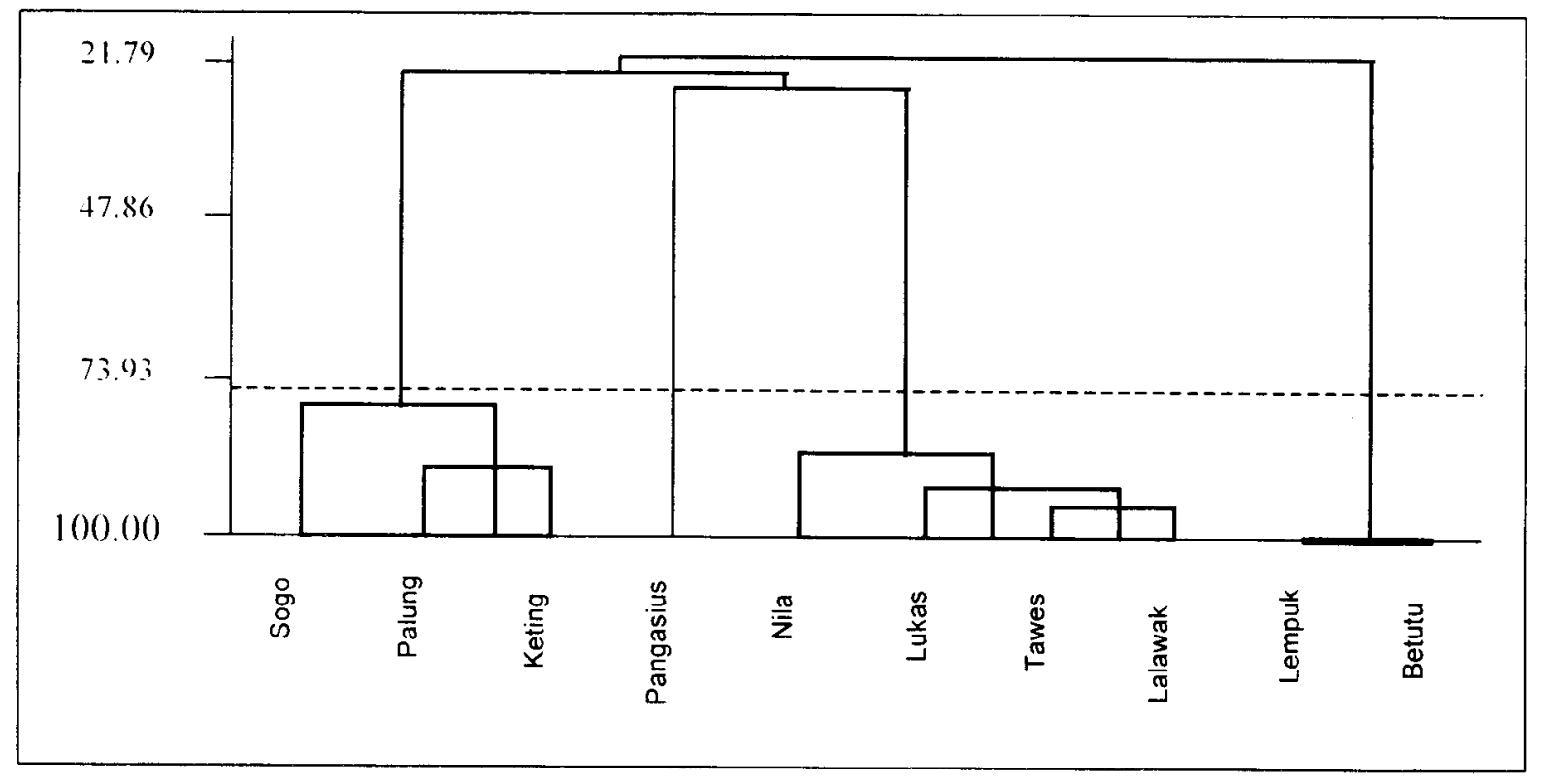

Gambar 6. Dendogram pengelompokan ikan berdasarkan kesamaan makanannya Figure 6. Dendrogram indicating the similarity of fish diets 
pasarnya juga tinggi. Seorang pengumpul ikan ini di Desa Wonoharjo Kecamatan Nguntoronadi mampu mengumpulkan $150 \mathrm{~kg} / \mathrm{hari}$ dan dijual dengan harga Rp 50.000,-/kg. Tampaknya ikan tersebut tidak khusus untuk memenuhi konsumsi lokal (harganya terlalu mahal) tetapi juga untuk diekspor.

\section{KESIMPULAN}

- Struktur komunitas ikan di Waduk Wonogiri didominasi oleh populasi ikan herbivora, terutama tawes, lukas, lalawak, dan nila. Kehadiran ikan nila mampu menduduki relung ekologi ikan asli sehingga kompetisi yang ditimbulkannya dikhawatirkan dapat mendesak populasi ikan asli.

- Keberadaan ikan pangasius mampu mengisi relung ekologi yang kurang dimanfaatkan oleh populasi ikan asli sehingga peluang kompetisi makanan dengan jenis ikan yang lain relatif kecil.

- Ikan betutu berdasarkan kesamaan relungnya hanya berpeluang untuk kompetisi makanan dengan ikan lempuk yang juga bersifat karnivora. Jenis ikan tersebut juga cocok untuk dikembangkan sebab makanannya spesifik yaitu udang

\section{DAFTAR PUSTAKA}

Colwell, I.C. and D.J. Futuyma. 1971. On the measurement of niche breadth and overlap. Ecology, 52:567576.

Cowx, L.G. 1994. Stocking strategy. Fisheries Management and Ecology. (1):15-30.

Cowx, I.G. 1998. An appraisal of stocking strategies in the light of developing country constraints. In T. Petr (ed). Inland fishery enhancements. Paper presented at the FAO/DFID. Expert consultation on inland fishery enhancement. Dhaka, Bangladesh, 7-11 April 1997. FAO Fish. Tech. Pap. No. 374. Rome. p:119-132.

Effendie, M.I. 1979. Metoda Biologi Perikanan. Yayasan Dewi Sri. Bogor. 112 pp.

Giller, P.S. 1984. Community Structure and the Niche. Chapman and Hall. New York. 153 pp.

Kartamihardja, E.S. 1992. Beberapa aspek bio-limnologi dan pengelolaan perikanan di Waduk Wadaslintang, Wonosobo, Jawa Tengah. Bull. Penel. Perik. Darat. Vol. 11 No. 1. p.1-11.

Krismono, D.W.H. Tjahjo, A. Hardjamulia, S. Nuroniah dan C. Umar. 1987. Penelitian limnobiologis Waduk Saguling pada tahap post inundasi. Bull. Penel. Perik. Darat. Edisi Khusus. Vol. 6 No. 3. p.1-31

Moyle, P.B. and F.R. Senanayake. 1984. Resource partitioning among fishes of rainforest streams in Sri Lanka. J. Zool. London. 202:195-223.

Nielsen, L.A. and D.L. Johnson, 1985. Fisheries Techniques. American Fisheries Society, Bethesda, Maryland. $468 \mathrm{pp}$

Piet, G.J. 1996. (Ed.). On the Ecology of a Tropical Fish Community. M.C. Escher/Cordon Art-Boarn-Holland. $189 \mathrm{pp}$.

Umar. C. 1991. Distribusi plankton di Waduk Cirata, Jawa Barat pada tahun 1988-1989. Bull. Penel. Perik. Darat. Vol. 10 No. 1. p. 1-9.

Welcomme, R.L. and D.M. Bartley. 1998. An evaluation of present techniques for the enhancement of fisheries. In T. Petr (ed). Inland fishery enhancements. Papers presented at the FAO/DFID. Expert consultation on inland fishery enhancement. Dhaka, Bangladesh, 7-11 April 1997. FAO Fish. Tech. Pap. No. 374. Rome. p.1-36. 